\title{
Inflicting the Structural Violence of the Market: Workfare and Underemployment to Discipline the Reserve Army of Labor
}

\author{
Christian Garland
}

\begin{abstract}
"Taking them as a whole, the general movements of wages are exclusively regulated by the expansion and contraction of the industrial reserve army, and these again correspond to the periodic changes of the industrial cycle. They are, therefore, not determined by the variations of the absolute number of the working population, but by the varying proportions in which the working-class is divided into active and reserve army, by the increase or diminution in the relative amount of the surplus-population, by the extent to which it is now absorbed, now set free."[2]
\end{abstract}

- Marx, K. (1867)

\section{Inflicting the Structural Violence of the Market}

As the ongoing crisis of capitalism continues beyond its sixth year, the effects have been felt with different degrees of severity in different countries. In the UK it has manifested in chronic levels of underemployment which veil the already very high unemployment total that is currently hovering not far off the early 1980s levels of around three million. This data takes into consideration the official unemployment total and combines it with the number of Job Seekers Allowance (JSA) claimants now 'self-employed' who work in various odd jobs such as catalogue selling or holding an eBay account now claim Tax Credits to supplement their meager earnings. As such, "record falls in unemployment" and "record numbers in employment" are really not what they seem. This paper will critically outline some of the key features of underemployment and workfare in 'dispossessing the dispossessed' and in inflicting upon them the structural violence of the market, the legally sanctified market violence of capitalism, and the various forms this can be said to take. The underlying argument is that there remains the structural violence inherent in the capital-labor relation itself.

The financial crisis, continuous and showing no sign of abating, is in the UK context at least, following the end of the recession, now apparently 'over.' However, the economic and social paroxysms that began more than six years ago, as a crisis unlike anything previously experienced since the early Twentieth Century, stubbornly refuse to subside, regardless of how much austerity is applied politically.

Indeed, capital's necessity for further accumulation and its own valorization at any cost means that crisis remains always present. By this, is not meant merely any 'crisis of capitalism,' 'boom and bust' or 'disequilibrium in the economy,' but instead the fact that for capital to exist systemically it must reproduce value and extract profit, and in doing so, accumulates crisis, the crisis of the very basis for this accumulation being labor. Capital is dead labor, that, vampire-like, only lives by sucking living labor[3] and dead labor (that is abstract labor stored up as accumulation) finds living labor increasingly unnecessary for self-valorization. In other words, the capacity for work or wage labor to feasibly exist can be discerned in the crisis of the capital-labor relation itself which finds material expression in wage labor that is increasingly elusive, insecure, and is a precarious privilege for a growing and substantial number 
of people.

Indeed, as has been said, in outlining the terms of dispossession it is possible to speak of a legally sanctified market violence, and the various forms this can be said to take. By this is meant the structural violence inherent in the capital-labor relation itself, one which is always not only unequal and one sided, but determined utterly by one side, capital. Capital being an abstract social relation formed by living labor, once rendered dead, accumulated abstract labor reverses this dependency and in so doing determines the very terms of material existence in a world in which wage labor is the means through which 'labor' materially reproduces itself. This structural violence of the market is shored up by the cruder and only sometimes immediately apparent violence of the state, there are the measures taken to alter the co-ordinates of capitalist society to the of capital and the capitalist class: 'creating an attractive environment for investors,' being the frequently preferred euphemism especially. Employed labor, as for its unemployed reserve army, is also disciplined by the threat of 'workfare,' the umbrella term used for programmed targeting the unemployed, us material compulsion, that is, the direct or indirect threat of benefit withdrawal for non-compliance: actual destitution being the threat underlying it. As such, the necessity for flexibility in the capitallabor relation flexibility meaning the flexibility of labor to adapt to its situation capital renders the precarious and insecure existence of a substantial section of the majority, an apparent privilege: for that section in temporary and indeterminate possession of it, and of course that fluid section cast adrift.

Dispossessing the dispossessed then, refers to the class location of that section of the majority most immediately affected by the state's efforts to attempt to restructure and reform the existing terms of existence for the side of labor to better serve the imperatives of accumulation and the production of value. In such a relation, the privilege of wage labor only ever relative to the reproduction of that labor becomes scarcer and more precarious at the exact same time as it is rendered disconnected utterly from any notion of necessity.

Underemployment refers to the precarious situation of those unable to secure full-time wage labor, who must settle for part-time hours while trying to meet full-time costs, something fully realized in zero hours contracts. In the crisis of the capitalist economy, myriad forms are found for shifting this back onto populations, the contemporary notion of austerity the most notorious and keenly felt.

Precarious or contingent employment, underemployment and the disjuncture of these with spiraling living costs, mark out a material terrain of dispossession for a growing number. To be sure, in the UK of 2015, economic recovery can be seen in the widespread existence of food banks and payday lenders, throwing stark light on the harsh social reality of austerity and unconvincing governmental attempts to veil the actual nature of such efforts to shore up the capitalist economy: arguably the most reprehensible of these being the removal from official figures of all those forced onto some version of workfare, or under 'sanction' (having their subsistence benefit withdrawn) thus making the total appear lower than it actually is.

The crude violence of rendering people destitute by depriving them of the very minimal means the state defines as subsistence can be seen in the number of suicides following the sanctioning of claimants. The fact that welfare reform in this case the exponential increase in the use of sanctions for perceived infractions of the rules should be directly linked with many dozens of suicides is unique to the formerly incumbent DWP regime.

'Figures released under the Freedom of Information Act show that 3,097,630 Job Seekers Allowance (JSA) claims were made in 2013-14 and 568,430 individuals were subject to a sanction, a total of $18 \%$. In 2012-13, $16 \%$ of claims were subjected to sanctions and $15 \%$ in 2010-11. They are imposed on people who fail to keep appointments, reject jobs or walk out of jobs without good reason.[4]

In 2008-09, only 286,694 sanctions were applied on the 2,935,930 JSA claims, representing 10\%[5]. Indeed, the DWP is currently in the midst of its own inquiry into 60 suicides directly related to its benefits sanctions regime.[6] Although the results of that have yet to be made public it is safe to say that 'no evidence' will be found, in the true terms of the state investigating itself. It should be emphasized however, that simply because 'no evidence is found' for something, it does not mean that the evidence doesn't exist. David Webster, honorary senior research fellow at the University of Glasgow has noted, 'The DWP is still regularly claiming that it is only a 'tiny minority' of claimants who are sanctioned - most recently by Esther McVey last week - but this suggests it is not a tiny minority. [7]

\section{| 'Look for More or Better Paid Work': Workfare Targeting the Underemployed}

The formerly incumbent coalition and now wholly Conservative DWP regime has over the past 5 years, gone 
out of its way to make life as difficult as possible for unemployed claimants, no less than all those in receipt of Employment Support Allowance (ESA). ESA claimants are the sick, disabled, and those with incurable conditions such as MS and Parkinson's who are deemed fit for work en masse following the humiliation of the so-called 'Work Capability Assessment' carried out by Atos Healthcare, something which has led to the deaths or suicides of at least 10,000 people. [8] Protests against Atos in fact led to the company ending its $f, 500$ million contract with the DWP a year early, and being replaced by the workfare multinational Maximus.[9]

While the mass application of sanctions and workfare has indeed been beyond anything even resolute critics of 'welfare reform' could have expected, there is also the indeterminate roll out of 'Universal Credit' which will place all those claimants who are also underemployed under the same performative demands of the Job Centre. The same performative demands, which should they still wish to supplement their meager earnings with benefits of some kind will mean them facing the same punitive measures of workfare and sanctions JSA claimants already face. A further additional and comparatively new government habit is to reclassify those who were formerly unemployed by mass signing off and registration as self-employed,[10] thus achieving 'record falls in unemployment' and 'record numbers in employment.' What is not mentioned is the fact that the overwhelming majority of newly self-employed former claimants are doing some sort of piece work such as selling catalogues door-to-door, or running an account on eBay, struggling to make their former income of JSA with Tax Credits.

This unwelcome tightening of the screw made by both state and capital, is also the pacification of employed labor, since the most basic rudiments of capitalism are to cut costs none being costlier than wages and to increase profits, the employer can do no better than eliminate the cost of wages altogether by using unpaid labor mandated to do the same work. This pacification of labor of course, also undercuts those employed and paid wages for their trouble, since it lowers the relative value of their own labor, which it should be restated is never more than relative to the cost of its reproduction.

When it is considered that in the UK, the underemployed including in that definition all subsections of the category combined with the much higher number who are unemployed, comprise roughly one third of the total workforce, the full reality of 'recovery' becomes clearer. It is worth repeating also, what is meant by recovery: the recovery of capitalism, its return to profitability, which demands at every turn, the minimization of costs, foremost among those being wages, assuming wage labor is required at all, for so far as it may sometime be, 'there is at the same time a widening of the social chasm that divides the worker from the capitalist, an increase in the power of capital over labor, a greater dependence of labor upon capital'.[11]

Underemployment, understood as the terminal disjunction between labors having the at least relative means for its social reproduction, that 'full time' wage labor gave it is possible to discern a definite market discipline in operation. Capital, seeking always to drive down the cost of labor, aims to reduce it as far as possible. The two sides always existing as diametric opposites:

'They stand in inverse proportion to each other. The share of (profit) increases in the same proportion in which the share of labor (wages) falls, and vice versa. Profit rises in the same degree in which wages fall; it falls in the same degree in which wages rise.'[12]

The market discipline of a chronic shortage of wage labor yielding enough in wages that is in a limited amount of part-time, casualized, and flexible employment, as capital reaches the point 'as an independent social power i.e., as the power of a part of society it preserves itself and multiplies by exchange with direct, living labor" that being the obsolescence of a greater or lesser section 'of a class which possesses nothing but the ability to work', is the fragmented and diffuse abstract that 'is a necessary presupposition of capital.'[13]

Illustrating the point, according to the DWP project known as 'Universal Credit,' to replace all existing benefits en bloc, the tyranny of underemployment will meet the tyranny of workfare and sanctions. The tyranny of workfare and sanctions speaks for itself: conscription of claimants to work unpaid or be made to 'volunteer', or risk losing their only income of JSA. Anyone needing to supplement meager wages with benefits of some kind will be obligated to 'look for more or better paid work,' or be under the same workfare and sanctions.[14]An explanatory memorandum accompanying the legislation:

- '216. Claimants will be subject to work related requirements intended to help them move into work, progress in work or prepare for work in the future.

- 217. Claimants will fall into one of the following conditionality groups [...]. "All work related requirements: claimants we expect to move into work, more work or better paid work. All Work-Related Requirements Group 
- 233. This will be the default group for all claimants unless they fall in the work focused interview or work preparation groups.

- 234. Claimants in this group will be required to look for and be available for work. This will usually be full time (i.e. for their expected hours of work) and of any type'[15].

The various programs, termed workfare, have historically been the state's efforts to 'put the unemployed to work' and 'make the unproductive productive' without them actually being employed. However, workfare has faced serious and concerted opposition and contestation in the last few years both politically and legally. Legal opposition to workfare began in 2012, when two claimants, Cait Reilly and Jamison Wilson,[16] who had been sent to work unpaid as a condition of being able to claim Job Seeker's Allowance (JSA), launched a court case against the DWP,[17] arguing that this amounted to forced labor, and was therefore unlawful.[18] The Appeal Court ruled that such schemes were legally flawed; quashing the regulations underpinning them the DWP subsequently rushed through replacement legislation as a response.[19] Reilly had been compelled to give up her volunteering role at a museum something closely related to her chosen field and been made to 'accept the help that is offered'[20] in the form of another of the punitive schemes: a 'Sector-Based Work Academy.'[21]

It could be concluded here that the essence of what cover the now seven variants of what are grouped under the umbrella term, 'workfare' are distilled in the case of Cait Reilly and Jamison Wilson: material compulsion to discipline the reserve army of labor, and much ideological baggage of the starry-eyed positive thinking kind to veil the punitive nature of what claimants are faced with.

\section{Franchising the Workhouse: The contemporary UK context}

It can be contended that there is something of an absurd irony in the fact that private companies tasked with imposing workfare on the unemployed, sick and disabled, now make up what is a growth industry. In a society based on precarious and 'flexible' wage labor, which demands that the overwhelming majority of the population work at all costs, even if there is not in fact enough actual wage labor available, work assumes once again, a virtuous ethic of self-discipline, pious resolve, and thrift, comprising an ideological narrative of 'self-help' and 'individual responsibility.'[22] This narrative of the inherent virtue of work aims at shifting the burden for unemployment back onto the shoulders of the individual: societal problems become individual failings, and a matter of 'not trying hard enough', just as 'there is work out there, but some people don't want to work.' The workfare industry applies the existing state model of material compulsion and elements of the same ideology of work as being a good in and of itself,[23] regardless of whether the person engaged in it is paid enough to reproduce their labor power which, it is worth remembering, is only ever the relative value of wage labor.

It may be contended, that workfare is also a composite part of the project of 'security' that is, securing the terrain of exploitation for capital at any and every cost. The fact that capital and state work together to achieve such an outcome is well crystallized in workfare: the state seeks to pacify the reserve army of labor while cutting its limited benefits once seen as a minimal guarantor of relative social peace while an entire industry springs up comprised of capitalist enterprises specialize in drilling individuals, thrown into the labor surplus, with 'work discipline' as they undertake imposing the state's outsourced punitive measures and ideology of workfare. Indeed in the contemporary UK, the Conservative-led coalition, now regrettably a Conservative majority in its own following this year's General Election right albeit a very slim one, made itself with 'welfare reform,' the decades long project a key element of neoliberalism to lessen the so-called 'welfare state,' and restructure it to better serve the needs of capital, a task governments of all shades since the 1980s. This restructuring of the welfare state, can be seen as part of a wider and even longer term restructuring of the labor market, and its alignment with 'flexibility'- insecure, expendable, and atomized labor being instantly replaceable with equally insecure, expendable, and atomized labor. The 'rigidities' are observable in unionized workforces taking collective action to resist wage stagnations and reductions, redundancies, and the ever-present demands of capital on labor to speed up. Workfare, (and also 'welfare-to-work') is the imposition of market discipline in order to further limit the contradiction of capital and labor through the latter's pacification.[24]

The pacification and compliance of a reserve army of labor under constant threat of sanction for not embracing its own servitude with the requisite enthusiasm, provides capital with a pliable and expendable workforce as and when required.[25] Workfare is also supported by the Victorian workhouse ideology of the deserving and undeserving poor, and self-help which individualizes unemployment making social and societal problems into individual moral failings,[26] albeit having received a twenty-first century gloss of 'empowerment' aimed at 'fulfilling potential'. 
Indeed, the lucrative workfare industry specializes in such positive thinking to explain its own role in claimants being 'helped into work,' or somewhat tellingly, 'nearer to the labor market' workfare has very little effect in securing actual employment:

'There is little evidence that workfare increases the likelihood of finding work. It can even reduce employment chances by limiting the time available for job search and by failing to provide the skills and experience valued by employers. [...] Workfare is least effective in getting people into jobs in weak labor markets where unemployment is high.'[27]

It is thus insightful that the state sees fit to make its minimal contribution to keeping the unwanted surplus at supposedly subsistence level conditional, as this same reserve army is expected to assume full responsibility for its own superfluity while meeting performative demands, or face sanctions.

As Marx' capitalism is a system predicated on the exploitation of labor for profit, that is, the appropriation of the wealth of a society that is itself produced by labor, for capital.

\begin{abstract}
'We thus see that, even if we keep ourselves within the relation of capital and wage-labor, the interests of capital and the interests of wage-labor are diametrically opposed to each other. To say that "the most favorable condition for wage labor is the fastest possible growth of productive capital", is the same as to say: the quicker the working class multiplies and augments the power inimical to the wealth of another which lords over that class the more favorable will be the conditions under which it will be permitted to toil anew at the multiplication of bourgeois wealth, at the enlargement of the power of capital, content thus to forge for itself the golden chains by which the bourgeoisie drags it in its train.'[28]
\end{abstract}

Capital is itself a social relation, and one that is based on the imperative of always needing to drive down the cost of labor, in fact as far as possible, to do away with it, even though capital needs labor simply to exist. As such, the reduction in wages, will try to be as far as possible symmetrical with the increase in the volume of work. Labor must be made to work harder, longer, and for less, the better that capital can reproduce surplus value, and extract profit, for 'profit and wages remain as before, in inverse proportion.'[29] Capitalist enterprises, and the institutions serving capitalist society, benefit greatly from labor's docility, and for those in employment, there is the actual sometimes implied threat of unemployment. However inherently exploitative wage labor may be, it does at least allow the wage laborer to reproduce their material existence; to have this privilege withdrawn, is to be effectively erased from material existence itself.

As capital accumulation reaches a certain level, it throws off far more labor than can be reasonably exploited, and so a continuous surplus becomes ever-more apparent, and is felt by the side of labor all the time by its own superfluity, its social extraneousness.

\title{
| 'Offered the House and Nothing Else...'[30] The Genesis and History of Workfare
}

Additionally, and in support of the efforts of government policy, largely irrespective of incumbent administration though more crudely apparent in the present UK context, there is the media propaganda war making use of a narrative of imaginary 'lazy-feckless-workshy-scroungers', who have 'chosen' the 'lifestyle' of unemployment.[31] The rhetoric of welfare reform, now nakedly revealed for what it always was as workfare truly came into its own in 2012 with Iain Duncan-Smith's workhouse ideology underlying his emphasis on conditionality as the basis for Universal Credit, itself the centerpiece of the 2012 Welfare Reform Act.[32] Besides this, the different versions of workfare all seek to impose this burdensome ideological weight on the shoulders of claimants, making them believe that they are responsible for unemployment, and are to blame for being workless. The grim rectitude of this unsparing validation of the inherent good of work is especially insightful for contemporary Critical Theory, since besides the ideology it espouses, there is the very real material compulsion of severely limited benefits being sanctioned, sometimes for up to three years.

The society of which workfare is a composite part, can be seen as the state of exception become the rule, of the structural violence of capitalism having become that much cruder and more brutish, workhouse ideology albeit a twenty-first century incarnation and the material compulsion of market discipline, replacing a modicum of social security as the price for capital and the state tolerating unwanted surplus labor. This ideological figment of the deserving and undeserving poor is always at work in the punitive policy of workfare, as much as the media narrative promulgating it. Such a division of the proletariat against itself, by an arbitrary separation of those who 'deserve' 
the help of society and those who 'choose' the 'lifestyle' this affords, has a long history which pre-dates even the idea of a so-called welfare state, going back in modern form in Britain arguably to the Act for the Relief of the Poor 1597 and Poor Relief Act 1601, followed by the Relief of the Poor Act 1782 and 1824 Vagrancy Act, finding its most notorious expression at the dawn of industrialization in the Poor Law Amendment Act 1834. The violent displacement of industrialization and capital accumulation of the Eighteenth and Nineteenth Centuries saw the bringing into being of a working class made dependent on wage labor. Without anything but its labor to sell, surplus labor was as unwanted and problematic requiring discipline to maintain its docility — a punitive process always on the very edge of its.

As far as labor could be usefully exploited by capital, it would at least survive, but having nothing besides itself to sell, material compulsion was the constant driving force, and as soon as wage labor became unavailable, labor, the proletariat, experienced the other freedom it had been granted by the market, the freedom to starve. As such, the newly created urban poor became a problem to be dealt with, being, as they were, formally free and under no feudal obligation, but without the means to survive. Earlier Poor Laws unsurprisingly, made the task of social welfare provision such as it was, the task of the Church, until the Tudor dissolution of the monasteries, belatedly made it the concern of the state in the form of rate contributions via counties and the parish.

The consolidated and synthesized earlier legislative programs to divide the poor into deserving and undeserving, and as such, was also the first properly modern structuring of social space to make the whole of life in accord with the demands of capital accumulation. The working class went to the factory and mill to labor to be paid wages relative to subsistence: those members of this class cast off by capital and thus removed from the wage relation became the urban poor, a dangerous group that has haunted capitalist society for as long as it has existed. To be sure however, this dangerous group is not and never has been a separate class from the proletariat, merely a section of it, but one that (re)appears as the visible prelude to the real reckoning of history, which haunts capitalism. [33] The essence of the 1834 Act, and its role in the modern structuring of social space was distilled in the so-called 'workhouse test' and the administering of 'indoor' and 'outdoor' relief, the latter being the granting of 'relief' to those otherwise still granted their freedom, and as such something to be discouraged and limited in practice. 'Indoor relief' was of course the degradation and brutalization of the workhouse, virtually indistinguishable from prison. The urban poor were thus considered undesirable, and to be at best tolerated and pacified through a punitive and limited system of 'assistance', but one in which little presence was made to disguise its function: containment. One hundred and eighty or so years later and in updated and postmodern or liquid modern form, there is workfare, just as via the global restructuring and class re-composition of global capital, there is chronic underemployment to inflict the structural violence of the market and dispossess the dispossessed.

\section{Conclusion}

It has been argued here is best understood as the disciplinary bulwark used against unwanted surplus labor to forcibly mobilize it in a continuous struggle for material justification of its existence. What is especially invidious about workfare is that compulsion is as far as possible left to the dull compulsion of material forces, and individualized accordingly. [34] The fact that, to quote Tesco's own PR response to queries about its participation in offering unpaid traineeships as part of 'Help to Work,' 'most young people refer themselves' [35] is very much in keeping with selfmanaged or self-service servitude, in that at every turn, this is individualized so the individual becomes the one who locks themselves in their cell.

To be sure, the franchises of workfare are the private partners of the state, that model of the market delivering what remain state functions, and with the legal blessing to act accordingly. This model of contracting out state functions and services was especially beloved by New Labour, who could claim, quite truthfully, that it was 'not privatization'. From virtually all public services, to the repressive machinery of policing and prisons, private third, fourth and fifth parties bid for the tender, the successful bidder gaining very lucrative revenue streams lasting several years at a time. Third, fourth and fifth party private workfare contractors deliver punitive workfare measures for the state which means of course, enforcing measures become ever more punitive. With this in mind, the progressive withdrawal of very basic state provision of social security and its replacement with a punitive workfare regime, what Zygmunt Bauman might call a shift in governmental priorities [36] has created a new market all of its own for companies to profit from unemployment. Indeed, the likes of A4E, Avanta, and Serco, are not, and never have been 
concerned with finding what are in fact non-existent jobs for those mandated to their 'services' by the Job Centre, but in the telling language of the DWP itself, tackling 'worklessness'. 'Worklessness' is itself a term uniquely derived from workfare rhetoric, itself underlined by the 'dull compulsion of economic relations' [37] infused by the same material compulsion and sanctimonious shopkeeper moralism of 'individual responsibility' to break the 'dependency' of being unemployed or in receipt of benefits, something to which the poor must 'adapt themselves' [38] in essence, blaming the unemployed for being unemployed, and the poor for being poor.

This example is useful for illustrating the concept of 'self-exploitation' already outlined: the surplus labor of capital, cast off as surplus to requirements, that being to be usefully exploited in the production of value and the extraction of profit, is made so indirectly through material compulsion: the individualized responsibility for servitude. Tesco along with many other companies and charities gets indentured labor for free, and as for the scheme being 'over-subscribed,'[39] that can easily be traced back to Job Centre advisers and/or workfare brokers offering unemployed youth (and other claimants) the choice of agreeing to it, but considering the alternatives involve being moved onto a different workfare scheme, or very likely facing sanction, the voluntary nature of workfare is cast in its own harsh light. Such a roundabout way of putting the unemployed to work' even when it is not for the usual basic remuneration of wages,[40] can certainly be understood as a state measure aimed at guaranteeing social peace, of course subcontracted in delivery by the market and like underemployment an ance opaque and complex, but ultimately very simple institutional and commercial operation of the structural violence inherent in the capital-labor relation.[41]

\section{Endnotes}

1. A version of this paper was presented at the Critical Legal Conference: Power, Capital, Chaos 4-6 September 2014, University of Sussex. [Last accessed: 28 May]

2. Karl Marx, Marx, K. (1857) Capital Volume One, Chapter Twenty-Five: The General Law of Capitalist Accumulation, Section 2. Relative Diminution of the Variable Part of Capital Simultaneously with the Progress of Accumulation and of the Concentration that Accompanies it, http://www.marxists.org/archive/ marx/works/1867-c1/ch25.htm\#S2Ibid [Last accessed 31 May 2015]

3. Marx ibid.

4. Iain Duncan Smith rapped by watchdog for misusing benefits cap statistics', Ball, James. The Guardian, 9 May 2013 http://www.theguardian.com/society/2015/ feb/13/record-number-of-sanctions-imposed-onjobseekers

5. Iain Duncan Smith rapped by watchdog for misusing benefits cap statistics', Ball, James. The Guardian, 9 May 2013 http://www.theguardian.com/politics/2013/ may/09/iain-duncan-smith-benefits-cap-statistics

6. 'Record number of sanctions Imposed on jobseekers', Wintour, Patrick. The Guardian 15 February 2015 http://www.theguardian.com/society/2015/feb/13/ record-number-of-sanctions-imposed-on-jobseekers [Last accessed: 28th May 2015]

7. 'Suicides highlight the grim toll of benefit sanctions in austerity Britain', Cowburn, Ashley. The Observer,
3 January 2015 http://www.theguardian.com/ society $/ 2015 / \mathrm{jan} / 03 /$ benefits-sanctions-leadingsuicides-dwp-depression [Last accessed: 28th May 2015]

8. 10,600 people have died after being declared 'fit for work' by Atos - join demonstrations today' http://union-news.co.uk/2014/02/unions-join-antiatos-demos-today-10600-people-die-declared-fitwork/\#sthash.8L0nUotK.dpuf [Last accessed: 28th May 2015]

9. 'Atos Quitting $£ 500 \mathrm{~m}$ 'Fit-For-Work' Contract Early, DWP Confirms' The Huffington Post UK, Bennett, Asa 27 March 2014, http://www. huffingtonpost.co.uk/2014/03/27/atos-quits-benefitscontract_n_5040557.html [Last accessed: 28th May 2015]

10. 'Self-employment in UK at highest level since records began', Monaghan, Angela. The Guardian http://www.theguardian.com/uk-news/2014/aug/20/ self-employment-uk-highest-level [Last accessed: 28th May 2015 'Self-employed workers in the UK 2014' Office for National Statistics, 20 August 2014, http://www.ons.gov.uk/ons/rel/lmac/self-employedworkers-in-the-uk/2014/rep-self-employed-workersin-the-uk-2014.html [Last accessed: 28th May 2015]

11. Marx, K. (1847) Wage Labour and Capital https:// www.marxists.org/archive/marx/works/1847/wagelabour/

12. Marx ibid 37. 
13. Marx ibid 30.

14. 'UK's lowest-paid employees to be classed as 'not working enough', Shiv Malik, The Guardian, 7 September 2013 http://www.theguardian.com/politics/2013/ sep/06/uk-lowest-paid-classed-not-working-enough [Last accessed: 28th May 2015 ]

15. Explanatory Memorandum for the Social Security Advisory Committee, DWP Universal Credit Regulations, for the meeting of the Social Security Advisory Committee, 13 June 2012 http:// www.guardian.co.uk/society/2010/oct/01/benefitsuniversal-credit-scheme [Last accessed: 28th May 2015]

16. Ibid.

17. BBC News: "Graduate 'made to stack shelves' seeks judicial review" quoted by Public Interest Lawyers, http://www.publicinterestlawyers.co.uk/news_details. php?id=200 [Last accessed: 28th May 2015]

18. Shiv Malik, "Poundland ruling 'blows big hole' through government work schemes", The Guardian 12 February 2013, Accessed 25 March 2014http://www. theguardian.com/society/2013/feb/12/poundlandruling-government-work-schemes [Last accessed: 28th May 2015]

19. Jobseekers (Back to Work Schemes) Act 2013. 28th May 2015]

20. This is the insipid wording of the existing legislation.

21. 'Sector- Based Work Academies' are one of the now seven workfare schemes, the others being: the 'Community Action Programme', 'Mandatory Work Activity', the flagship 'Work Programme', and 'Work Experience' being the older variants. 'Help to Work' encompassing 'Community Work Placements' in which claimants are made to work up to 35 hours a week unpaid for the benefit of the community, or attend a Job Centre each day for the same number of hours a week are the newer and more punitive variant. Traineeships, meanwhile, target unemployed young people who lack qualifications, and force them to work full-time unpaid for commercial enterprises such as Asda, Sainsbury's, and TK Maxx. All such schemes are indeed compulsory more or less - pace the DWP's claims of their 'voluntary' nature, and operate using different interpretive trip wires. The Job Centre advisor and/or workfare third, fourth, or fifth party having rather more space to 'interpret' whether or not a claimant is 'engaging', with "the help that is offered" to them, than the harried claimant. Should the claimant be deemed not to be 'engaging', they can be and usually are 'sanctioned' meaning their JSA - and only income - is withdrawn, sometimes for up to three years.

22. Sharon Beder (2001) Selling the Work Ethic: From Puritan Pulpit to Corporate PR (London: Zed Books)

23. P. Anthony (2009) The Ideology of Work (London:
Routledge)

24. "216. Claimants will be subject to work related requirements intended to help them move into work, progress in work or prepare for work in the future." Explanatory Memorandum for the Social Security Advisory Committee, DWP Universal Credit Regulations, for the meeting of the Social Security Advisory Committee, 13th June 2012, and also 'Universal Credit: welfare that works.' DWP. Presented to Parliament by the Secretary of State for Work and Pensions by Command of Her Majesty, November 2010

25. For more on the nature of 'workfare', see 'Private companies are making a fortune out of the unemployed', Ian Jack, The Guardian, 10th May 2014 http://www.theguardian.com/commentisfree/2014/ may/10/private-companies-making-fortune-outof-unemployed [Last accessed: 28th May 2015: ] see Crisp, R. and Fletcher, D. (2008) A comparative review of workfare programmes in the United States, Canada and Australia http://research.dwp.gov.uk/ asd/asd5/report_abstracts/rr_abstracts/rra_533.asp [Last accessed: 28th May 2015 ] see also http://www. boycottworkfare.org/ [Last accessed: 28th May 2015] and http://keepvolunteeringvoluntary.net/ [Last accessed:28th May], and Aufheben \#19 (2011) 'The renewed imposition of work in the era of austerity: prospects for resistance' http://libcom.org/library/ renewed-imposition-work-era-austerity-prospectsresistance [Last accessed: 28th May 2015] see and Aufheben \#21 (2012) Editorial: The 'new' workfare schemes in historical and class context http://libcom. org/library/editorial-\%E2\%80\%98new\%E2\%80\%99workfare-schemes-historical-class-context [Last accessed: 28th May 2015] see and Garland, C. (2014) 5 reasons workfare is coming undone http://wire. novaramedia.com/2014/07/5-reasons-workfare-iscoming-undone/ [Last accessed: 28th May 2015]

26. Berder, ibid.

27. 'A comparative review of workfare programmes in the United States, Canada and Australia' Crisp, R. and Fletcher, D. (2008) http://webarchive. nationalarchives.gov.uk/20130128102031/http:// research.dwp.gov.uk/asd/asd5/report_abstracts/rr abstracts/rra_533.asp

28. Marx. Wage Labour ibid.

29. Marx. Ibid.

30. This is a reference to the 1834 Poor Law Amendment Act, and the words of the Poor Law Commission in England and Wales which discouraged 'outdoor relief' instead stating, "all cases were to be 'offered the house', and nothing else" quoted in Fowler, S. (2007), Workhouse: The People: The Places: The Life Behind Closed Doors, The National Archives.

31. Voters 'brainwashed by Tory welfare myths', shows new poll, Grice, Andrew. The Independent , 4 
January 2013 http://www.independent.co.uk/news/uk/ politics/voters-brainwashed-by-tory-welfare-mythsshows-new-poll-8437872.html [Last accessed: 28th May 2015]

32. Welfare Reform Act 2012, CHAPTER 5, Explanatory.

33. Engels, F. (1845/2009) The Condition of the Working Class in England (Penguin: Harmondsworth)

34. Peck, J. (2001) Workfare States (New York: Guilford Press), and Shragge, E. (1996) Workfare: Ideology for a New Under-Class. (Toronto: Garamond Press)

35. Tesco Facebook response to anti-workfare campaigners, 16th July 2014

36. Bauman, Z. Liquid Fear. (2006) (Cambridge: Polity) p. 135

37. Marx. Ibid.

38. Marx. Ibid.

39. Tesco. Ibid.

40. 'Tens of thousands of unemployed people made to work without pay', Malik, Shiv, The Guardian, 15th February 2012 http://www.guardian.co.uk/ society/2012/feb/15/thousands-unemployed-workwithout-pay [Last accessed: 28th May 2015 ],

'Jobseekers forced to clean private homes and offices for free' Shiv Malik, James Ball, James. \& Lizzy Davies, The Guardian 25 February 2012 http://www.theguardian. $\mathrm{com} /$ politics/2012/feb/24/jobseekers-unpaid-workplacements [Last accessed: 28th May 2015],

'Unemployed bussed in to steward river pageant', Shiv Malik, The Guardian 4 June 2012 http://www. theguardian.com/uk/2012/jun/04/jubilee-pageantunemployed [Last accessed: 28th May 2015]

http://www.publications.parliament.uk/pa/ cm201415/cmhansrd/

cm140611/text/140611w0002.htm\# 14061165001750

[Last accessed: 28th May 2015].

Meanwhile, after lodging a third appeal with the High Court against having to publicly disclose the full lists of organizations involved in workfare, the DWP lost again, being ordered to make them publicly available, forthwith. 'The Upper Tribunal has dismissed DWP's appeal re "workfare" job seeker programmes.' https://twitter. com/hopkinsrobin/status/491600471426355200 [Last accessed: 28th May 2015 ] , 'The list of shame: Court tells DWP to reveal workfare users', http://www. boycottworkfare.org/?p=3680 [Last accessed: 9 March 2015] A very notable defeat for this most punitive variant of workfare yet, was inflicted in late July 2014, when Byteback IT Solutions Ltd, a Bristol-based IT reconditioning firm, touted a photo of chancellor George Osborne - an enthusiast for workfare - visiting them. The DWP had done likewise, since the 'flagship small business' 'subcontractor' had unemployed JSA claimants working for it unpaid, on 'Community Work Placements. Within a couple of days, the company had withdrawn due to the response on social media. 'IT Firm Pulls Out Of Workfare Scheme After George Osborne Visit' The Huffington Post UK, Bennett, Asa. 24 July 2014 http://www.huffingtonpost.co.uk/2014/07/24/ george-osborne-it-firm-workfare_n_5616281.html [Last accessed: 28th May 2015]. Earlier in April 2014, the Information Commissioner's Office (ICO) ordered the DWP to reveal the names of the organizations that provided placements on the 'Day One Support for Young People Trailblazer' pilot workfare scheme. http://ico. org.uk/ /media/documents/decisionnotices/2014/ fs_50520380.ashx [Last accessed: 28th May 2015]

41. The campaign against all forms of workfare has had some very notable successes - particularly via social media - in dozens of 'big name' companies and charities ending their involvement. So far, at least 40 have withdrawn, and another 400 voluntary organizations have helped make 'Help to Work', in which claimants can be mandated with indefinite 'full time' unpaid workfare or be made to sign on every day, an unmitigated disaster. Another 25 'big name' national charities have stated that they will not take part., whilst another 5 smaller organizations previously enthusiastic supporters of CWPs withdrew in a matter of hours following the response on social media. From its failed and fitful launch on, 'Help to Work' was meant to be up and running in May, and only in "very exceptional circumstances" could it be delayed to 2nd June, however Caroline Lucas MP found that this was delayed to 9th June across the board. Work and Pensions Access to Work Programme http://www. publications.parliament.uk/pa/cm201415/cmhansrd/ cm140611/text/140611w0002.htm\#14061165001750 [Last accessed: 28th May 2015].

Meanwhile, after lodging a third appeal with the High Court against having to publicly disclose the full lists of organizations involved in workfare, the DWP lost again, being ordered to make them publicly available, forthwith. 'The Upper Tribunal has dismissed DWP's appeal re "workfare" job seeker programmes.' https://twitter.com/hopkinsrobin/ status/491600471426355200 [Last accessed: 28th May 2015] , 'The list of shame: Court tells DWP to reveal workfare users', http://www.boycottworkfare. org/?p=3680 [Last accessed: 28th May 2015 ] 


\section{References}

P. Anthony (2009) The Ideology of Work (London: Routledge)

Aufheben \#19 (2011) The renewed imposition of work in the era of austerity: prospects for resistance http://libcom.org/library/ renewed-imposition-work-era-austerity-prospects-resistance

Aufheben \#21 (2012) Editorial: The 'new' workfare schemes in historical and class context http://libcom.org/library/editorial-\%E2\%80\%98new\%E2\%80\%99-workfare-schemes-historical-class-context [Last accessed 28th May 2015]

'Iain Duncan Smith rapped by watchdog for misusing benefits cap statistics', Ball, James. The Guardian 9th May 2013 http:// www.theguardian.com/politics/2013/may/09/iain-duncan-smith-benefits-cap-statistics [Last accessed 28th May 2015]

Bauman, Z. (2006) Liquid Fear (Cambridge: Polity)

BBC News: 'Graduate 'made to stack shelves' seeks judicial review' quoted by Public Interest Lawyers, http://www.publicinterestlawyers.co.uk/news_details.php?id=200 [Last accessed: 28 th May 2015]

Beder, S. (2001) Selling the Work Ethic: From Puritan Pulpit to Corporate PR (London: Zed Books)

'Atos Quitting $£ 500$ m 'Fit-For-Work' Contract Early, DWP Confirms' The Huffington Post UK, Bennett, Asa. 27 March 2014, http://www.huffington post.co.uk/2014/03/27/ atos-quits-benefits-contract_n_5040557.html [Last accessed: 28th May 2015]

'IT Firm Pulls Out Of Workfare Scheme After George Osborne Visit' The Huffington Post UK, Bennett, Asa. 24 July 2014, http://www.huffingtonpost.co.uk/2014/07/24/george-osborne-it-firm-workfare_n_5616281.html[Last 28th May 2015]

Boycott Workfare, (2014) 'The list of shame: Court tells DWP to reveal workfare users', http://www.boycottworkfare. org/?p=3680 [Last accessed: 28th May 2015]

'Suicides highlight the grim toll of benefit sanctions in austerity Britain', Cowburn, Ashley. The Observer 3rd January 2015 http://www.theguardian.com/society/2015/jan/03/benefits-sanctions-leading-suicides-dwp-depression [Last accessed: 28th May 2015]

'A comparative review of workfare programmes in the United States, Canada and Australia' Richard Crisp and Del Roy Fletcher. http://webarchive.nationalarchives.gov. uk/20130128102031/http://

research.dwp.gov.uk/asd/asd5/report_abstracts/rr_abstracts/ rra_533.asp

[Last accessed: 28th May 2015]

'Universal Credit: welfare that works.' DWP, Presented to Parliament by the Secretary of State for Work and Pensions by Command of Her Majesty, November 2010 https:// www.gov.uk/government/publications/universal-credit-welfare-that-works [Last accessed: 28th May 2015]
Explanatory Memorandum for the Social Security Advisory Committee, DWP, Universal Credit Regulations, for the meeting of the Social Security Advisory Committee, 13 June 2012 http://www.guardian.co.uk/society/2010/oct/01/benefits-universal-credit-scheme [Last accessed: 28th May 2015]

Engels, F. (1845/2009) The Condition of the Working Class in England (Harmondsworth: Penguin)

Fowler, S. (2007), Workhouse: The People: The Places: The Life Behind Closed Doors, The National Archives.

Garland, C. (2014) 5 reasons workfare is coming undone http:// wire.novaramedia.com/2014/07/5-reasons-workfare-is-coming-undone/ [Last accessed 31 May 2015]

Garland, C. (2014) Critical Legal Conference: Power, Capital, Chaos 4-6 September 2014, University of Sussex. [Last accessed 31 May 2015]

Voters 'brainwashed by Tory welfare myths', shows new poll, Grice, Andrew. The Independent, 4 January 2013 http://www. independent.co.uk/news/uk/politics/voters-brainwashedby-tory-welfare-myths-shows-new-poll-8437872.html [Last accessed: 28th May 2015]

'The Upper Tribunal has dismissed DWP's appeal re "workfare” job seeker programmes.' https://twitter.com/hopkinsrobin/ status/491600471426355200 [Last accessed: 28th May 2015]

Information Commissioner's Office (ICO) http://ico.org.uk/ / media/documents/decisionnotices/2014/fs_50520380.ashx [Last accessed: 28th May 2015]

Self-employment in UK at highest level since records began', Monaghan, Angela. The Guardian http://www.theguardian. com/uk-news/2014/aug/20/self-employment-uk-highest-level [Last accessed: 28th May]

'Tens of thousands of unemployed people made to work without pay', Malik, Shiv, The Guardian, 15th February 2012 http:// www.guardian.co.uk/society/2012/feb/15/thousands-unemployed-work-without-pay [Last accessed: 28th May 2015]

'Poundland ruling 'blows big hole' through government work schemes', Malik, Shiv. The Guardian 12 February 2013, http:// www.theguardian.com/society/2013/feb/12/poundland-ruling-government-work-schemes [Last accessed: 28th May 2015]

'Jobseekers forced to clean private homes and offices for free' Malik, Shiv. Ball, James. \& Davies, Lizzy. The Guardian 25th February 2012 http://www.theguardian.com/politics/2012/ feb/24/jobseekers-unpaid-work-placements [Last accessed: 28th May 2015],

'Unemployed bussed in to steward river pageant', Malik, Shiv. The Guardian 4 June 2012 http://www.theguardian.com/ uk/2012/jun/04/jubilee-pageant-unemployed [Last accessed: 28th May 2015] 
'UK's lowest-paid employees to be classed as 'not working enough', Malik, Shiv, The Guardian, 7 September 2013http://www.theguardian.com/politics/2013/sep/06/uk-lowest-paid-classednot-working-enough [Last accessed: 28th May 2015]

Marx, K. (1847) Wage Labour and Capital https://www.marxists. org/archive/marx/works/1847/wage-labour/ [Last accessed 28th May 2015]

Marx, K. (1857) Capital Volume One, Chapter Twenty-Five: The General Law of Capitalist Accumulation, Section 2. Relative Diminution of the Variable Part of Capital Simultaneously with the Progress of Accumulation and of the Concentration that Accompanies it, http://www.marxists.org/archive/marx/ works/1867-c1/ch25.htm\#S2Ibid. [Last accessed 28th May 2015

'Self-employed workers in the UK - 2014' Office for National Statistics, 20 August 2014, http://www.ons.gov.uk/ons/rel/ $\mathrm{lmac} /$ self-employed-workers-in-the-uk/2014/rep-self-employed-workers-in-the-uk-2014.html [Last accessed: 28th May 2015]
Jobseekers (Back to Work Schemes) Act 2013. 28th May 2015]

Peck, J. (2001) Workfare States (New York: Guilford Press)

Shragge, E. (1996) Workfare: Ideology for a New Under-Class. (Toronto: Garamond Press)

' 10,600 people have died after being declared 'fit for work' by Atos - join demonstrations today', Union News, http://union-news.co.uk/2014/02/unions-join-anti-atos-demos-today10600-people-die-declared-fit-work/\#sthash.8L0nUotK.dpuf [Last accessed: 28th May 2015]

'Record number of sanctions Imposed on jobseekers', Wintour, Patrick. The Guardian 15 February 2015 http://www.theguardian.com/society/2015/feb/13/record-number-of-sanctions-imposed-on-jobseekers [Last accessed: 28th May 2015] 
